Volume 12

Issue 2 Images And Collective Violence:

Function, Use And Memory

$10-2018$

\title{
Book Review: Rwanda before the Genocide: Catholic Politics and Ethnic Discourse in the Late Colonial Era
}

\author{
Randall Fegley \\ Pennsylvania State University Berks College
}

Follow this and additional works at: https://digitalcommons.usf.edu/gsp

\section{Recommended Citation}

Fegley, Randall (2018) "Book Review: Rwanda before the Genocide: Catholic Politics and Ethnic Discourse in the Late Colonial Era," Genocide Studies and Prevention: An International Journal: Vol. 12: Iss. 2:

188-189.

DOI:

https://doi.org/10.5038/1911-9933.12.2.1618

Available at: https://digitalcommons.usf.edu/gsp/vol12/iss2/14

This Book Review is brought to you for free and open access by the Open Access Journals at Digital Commons @ University of South Florida. It has been accepted for inclusion in Genocide Studies and Prevention: An International Journal by an authorized editor of Digital Commons @ University of South Florida. For more information, please contact digitalcommons@usf.edu. 


\title{
Book Review: Rwanda before the Genocide: Catholic Politics and Ethnic Discourse in the Late Colonial Era
}

\author{
Randall Fegley \\ Pennsylvania State University \\ Reading, Pennsylvania, USA
}

Rwanda before the Genocide: Catholic Politics and Ethnic Discourse in the Late Colonial Era

J. J. Carney

Oxford, Oxford University Press, 2014

337 Pages; Price: \$82 Hardcover

Reviewed by Randall Fegley

Pennsylvania State University

The Roman Catholic Church was Rwanda's most dominant institution in the period between 1920 and 1994. Carney's important work is the most recent history of Rwandan Catholicism in English. It carefully documents how "one of the most Catholic countries in Africa" descended into the depravity of ethnic particularism and mass death.

His first chapter, Contested Categories: A Brief History of Hutu and Tutsi, provides necessary historical, anthropological, and theoretical background on the development of group identities in Rwanda. Chapter 2, Building a Catholic Kingdom in Central Africa 1900-1950, discusses French Archbishop Charles Lavigerie, his development of the Missionaries of Africa (best known as the White Fathers), the Buganda missions in neighboring British Uganda, the first Catholic missions in Rwanda, World War I, the Belgian mandate of Ruanda-Urundi, French Vicar Apostolic Léon Classe and relations between the Europeans and the Tutsi monarchy.

Chapter 3, Success Breeds Restlessness 1950-1955, examines post-Second World War religious, political, and social transformations in Rwandan society. Particularly noteworthy are descriptions of the first Banyarwanda Bishop, Aloys Bigirumwami, Nyakibanda Seminary and the rise of the Swiss-born White Father André Perraudin. Continuing these themes, Carney's fourth chapter describes later, more dramatic changes that occurred in the political and religious spheres. Perraudin's influence became paramount and independence movements emerged among both ethnic groups. The Mwami Mutara's death and colonial machinations in its aftermath are covered in detail. The chapter ends with a discussion of the question, "Did the Catholic hierarchy incite an ethnic revolution?"

The fifth chapter, The Catholic Church and the Political Revolution in Rwanda 1959-1962, delves into the ascendancy of Hutu radical movements, particularly Parmehutu, and Catholic reactions to them. Perraudin rather than Bigirumwami became the unofficial primate of the Rwandan Church. As political events rapidly unfolded, an over-confident Church became increasingly reactive rather than proactive. As the road to independence became increasingly bloodied, the colonially rooted Church was "an epicenter radiating tensions," rather than the powerful force shaping public opinion it had been. The suspicious May 1961 death of Bernard Manyurane, the first Bishop of Ruhengeri, controversy in choosing his successor and tensions at the Nyakibanda Seminary later that year all limited the effectiveness of the Church at a time when moral commitment and peaceful resolution were needed the most.

Although the title of Carney's work leads one to think that he will conclude with the 1959 Hutu Revolution, his sixth and final chapter and epilogue provide vitally important links to the present. These include descriptions and analytical comments on the invasions and massacres of 1963-64, expulsions of Tutsi from schools in 1973, and finally, the church's role in the 1994 genocide. Although the Roman Catholic Church has contributed to rebuilding Rwanda, it has proven to be a flawed and weakened force, which allowed a situation to exist in which "the blood of tribalism ran deeper than the waters of baptism."

One of many great strengths of this history is its incorporation of the biographical details of particularly powerful leaders. In addition to those mentioned earlier in this review, they include Jean-Paul Harroy, the last Belgian colonial governor of Ruanda-Urundi (1955-1962); Tutsi priest and scholar Alexis Kagame; Grégoire Kayibanda, the Hutu seminarian who became Rwanda's first 
president; and his successor Juvenal Habyarimana, whose plane was shot down triggering the 1994 genocide.

A few appropriately placed maps and photos throughout the book illustrate the textual narrative. More would have been useful. Two very helpful appendices follow the text. Appendix I provides a timeline of relevant events occurring between 1884 and 2010. Appendix II is divided into two glossaries, one on key terms and acronyms in Kinyarwanda and French, the second provides biographical information on key historical personalities.

Carney's book covers a lot of ground. No doubt, he encountered difficulties in deciding what to include or not. He rightly focuses on events in Africa. However, his book could have benefited by some discussion of the vitally important changes that occurred in Belgium during the period he covers. Founded in 1830, Belgium was dominated by a French-speaking elite throughout its first century. Following the First World War and accelerating after the Second World War, Belgium's oppressed Flemish majority gradually became politically empowered. At the same time Frenchspeaking Belgians became increasingly anti-clerical and disconnected from church affairs. These trends were reflected in Rwanda, where priests and colonial administrators were profoundly affected by what was happening in Europe. Seeing parallels with their own experience, many Flemings sympathized with the Hutu majority, who had been dominated by the minority Tutsi. Some Francophone Belgians emphasized the need to limit the then Tutsi-dominated Church. The realignment of political power in Belgium, therefore, led to changes in colonial policies, which hitherto favored the Tutsi and rather suddenly came to side with the Hutu. All of this led to a confusing situation hampered by deeply rooted colonialist assumptions.

However, despite whatever additions one might want to append to Carney's work, he has made an impressive effort to describe and analyze a complex situation with which few beyond the borders of Rwanda have any familiarity. Covering all the major personalities, organizations and opinions, he succeeds in presenting key features of modern Rwandan society and politics. This book is highly recommended for scholars, activists and library collections concentrating on African religion, colonialism and genocide. 